\title{
Immunoreactive Somatomedin C/Insulin-Like Growth Factor I in Urine from Normal Subjects, Pituitary Dwarfs, and Acromegalics
}

\author{
SUSUMU YOKOYA, SEIZO SUWA, HATAE MAESAKA, AND TOSHIAKI TANAKA \\ Department of Pediatrics, Kanagawa Children's Medical Center, Yokohama, and Department of Endocrinology \\ and Metabolism, National Children's Medical Research Center, Tokyo, Japan
}

\begin{abstract}
Using antibodies to somatomedin C/insulinlike growth factor $\mathrm{I}(\mathrm{SmC})$ produced in rabbits using the recombinant hormone, we have developed a radioimmunoassay for SmC. Gel-chromatography of urine revealed that the vast majority of immunoreactive $\mathrm{SmC}$ was eluted coincident with ${ }^{125} \mathrm{I}-\mathrm{SmC}$ and a small portion eluted with fractions having a mol. wt. range of 30,000-40,000. The SmC concentration in urine was determined by radioimmunoassay after ammonium sulfate extraction. Values did not ordinarily exceed $1 \mathrm{ng} / \mathrm{ml}$. When the values from normal subjects were expressed as $\mathrm{ng} / \mathrm{mg}$ creatinine, high levels were observed in the neonatal period. These values fell rapidly in infancy, declined more gradually in childhood, were slightly elevated at early puberty, and were lowest in adulthood. Urine SmC concentrations in 15 pituitary dwarfs were lower than the averages obtained from agematched control subjects, and six of them showed abnormally low values. Three patients with active acromegaly had high SmC values in urine. In conclusion, 1) $\mathrm{SmC}$ mainly of monomeric form, was immunologically detected in urine. 2) Radioimmunoassay for urine $\mathrm{SmC}$ revealed that values varied considerably with age in normal subjects and were partially dependent on the human growth hormone status. However, the full meaning of the findings remains to be elucidated. (Pediatr Res 23: 151-154,1988)
\end{abstract}

\section{Abbreviations}

SmC, somatomedin C/insulin-like growth factor I

hGH, human growth hormone

BSA, bovine serum albumin

PBS, phosphate-buffered saline

RIA, radioimmunoassay

MSA, multiple stimulating activity

A number of the peptide hormones are known to be excreted in urine. Gonadotropins are detected in urine even from prepubertal children (1). Arginine vasopressin, one of the smallest peptide hormones, is found in urine not only in much higher concentration than in plasma but also at the excretion rate that is strongly influenced by the hydration status (2). Immunoreactive $\mathrm{hGH}$ in urine has also been reported though its clinical significance has not yet been clarified (3).

$\mathrm{SmC}$ may be excreted in urine in light of its relatively low

Received July 24, 1987; accepted September 23, 1987.

Correspondence and reprint requests Susumu Yokoya, M.D., Yokohama-Minami-Kyosai Hospital, Mutsuura-cho 500, Kanazawa-ku, Yokohama, 236, Japan.

Supported in part by the research grant for "Designated Diseases" of the Japanese Ministry of Health and Welfare. molecular weight, but there has been no study of SmC excretion. The purpose herein was to detect immunoreactive $\mathrm{SmC}$ in urine, investigate its age-related changes in normal subjects, and determine its possible clinical significance in evaluating hGH status.

\section{SUBJECTS}

First morning urine was collected from 230 normal subjects (114 males and 116 females). They included 144 healthy school children of 6-14 yr of age whose urine specimens were originally collected for the purpose of mass-screening for renal disorders and were kindly supplied by Kanagawa Health Service Association. The subjects also included 22 newborns who were born uneventfully in Yokohama-Minami-Kyosai Hospital. The rest of the control subjects included 12 infants, 25 preschool children, three adolescents aged $16 \mathrm{yr}$, and 24 adults aged 25-45 yr; they were all healthy volunteers from the hospital staff and their families.

Fifteen pituitary dwarfs also were studied. The diagnosis was made in Kanagawa Children's Medical Center or the National Pediatric Hospital when the peak hGH concentrations were less than $10 \mathrm{ng} / \mathrm{ml}$ during two or more of the provocative tests with insulin, arginine, glucagon, L-dopa, or clonidine. They included four patients with hypopituitarism of organic origin. Four of the subjects were adults who had completed their treatment with hGH more than 1 yr earlier, while the other 11 had not yet been treated with $\mathrm{hGH}$. Urine samples from three adults with active acromegaly and elevated plasma $\mathrm{SmC}$ levels also were examined.

\section{MATERIALS AND METHODS}

To assess the gel chromatographic pattern of immunoreactive $\mathrm{SmC}$ in urine, $20 \mathrm{ml}$ each of urine from a normal adult and a newborn were supplemented with $1 \mathrm{mg}$ of BSA (Armour Pharmaceutical Co., Kankakee, Ill), and dehydrated in dialysis tubing (Spectra/Por 6, mol. wt. cutoff 3500, Spectrum Medical Industries Inc., Los Angeles, CA) against powdered high molecular weight polyvinylpyrolidone (PVP-360, Sigma Chemical Co., St. Louis, MO). The sample was then dialyzed against 0.01 M PBS, $\mathrm{pH}$ 7.4. The urine concentrates (final $0.9 \mathrm{ml}$ ) were placed on a $0.95 \times 45 \mathrm{~cm}$ Sephadex G-100 (Pharmacia Fine Chemicals, Uppsala, Sweden) column and eluted with $0.01 \mathrm{M}$ PBS pH 7.4 containing $0.1 \%$ BSA. Each fraction was assayed by RIA for $\mathrm{SmC}$ as described below.

SmC produced by the recombinant DNA technique (lot no. B59165S) and rabbit anti-SmC antiserum were kind gifts from Fujisawa Pharmaceuticals Co., Osaka, Japan (4). Two $\mu$ g of SmC were radiolabeled with $0.8 \mathrm{mCi}$ of ${ }^{125} \mathrm{I}$ (New England Nuclear Corp., Boston, MA) by the chloramine $\mathrm{T}$ method (5). The iodinated hormone was purified on Sephadex G-50. The specific activity ranged between $300-350 \mu \mathrm{Ci} / \mu \mathrm{g}$. For the usual RIA, 300 
$\mu \mathrm{l}$ of samples or standards, $25,000 \mathrm{cpm}$ of ${ }^{125} \mathrm{I}-\mathrm{SmC}$ in $100 \mu \mathrm{l}$ $0.01 \mathrm{M}$ PBS containing $0.5 \%$ BSA, and $100 \mu \mathrm{l}$ of $1: 20,000$ diluted antiserum in the same buffer were vortex-mixed and incubated for $16-20 \mathrm{~h}$ at $4^{\circ} \mathrm{C}$. They were incubated another $2 \mathrm{~h}$ at $4^{\circ} \mathrm{C}$ after addition of $100 \mu \mathrm{l}$ each of 1:100 diluted normal rabbit serum and 1:20 diluted goat anti-rabbit $\gamma$ globulin (Eiken Chemicals Co., Tokyo, Japan). After centrifugation and aspiration, the radioactivity from the precipitates was counted. The cross-reactivity of rat MSA and porcine insulin in this system were less than $0.1 \%$. BSA used here did not contain SmC as a contaminant, because a large amount (up to $2 \mathrm{mg} /$ tube) of BSA added to the RIA system did not alter the tracer binding.

Routine measurement of SmC in urine was made by RIA after ammonium sulfate extraction. All the urine samples, to which $0.005 \mathrm{vol}$ of $6 \%$ sodium azide had been added, were stored at $4^{\circ}$ $\mathrm{C}$ up to 2 months until assayed. Four $\mathrm{ml}$ of the samples were supplemented with $20 \mu \mathrm{l}$ each of $0.6 \%$ BSA and glacial acetic acid (Wako Pure Chemical Ind., Osaka, Japan), vortex-mixed, and centrifuged at $3000 \mathrm{rpm}$ for $5 \mathrm{~min}$. To $1 \mathrm{ml}$ of the urine supernatant, $0.5 \mathrm{~g}$ of powdered ammonium sulfate was added to achieve approximately $75 \%$ saturation. The tubes were vortexmixed, allowed to stand for $30 \mathrm{~min}$ at room temperature, and centrifuged at $3000 \mathrm{rpm}$ for $30 \mathrm{~min}$. After aspiration of the supernatant, the pellets were dissolved and neutralized with 100 $\mu \mathrm{l}$ of $0.2 \mathrm{M} \mathrm{Na}_{2} \mathrm{HPO}_{4}, \mathrm{pH}$ 9.4. Another $200 \mu \mathrm{l}$ of $0.01 \mathrm{M} \mathrm{PBS}$, $\mathrm{pH} 7.4$, containing $0.5 \%$ BSA (assay buffer) was added to constitute $300 \mu \mathrm{l}$ of samples for RIA. All the urine samples were run in duplicate through the extraction and RIA steps.

Small amounts of ammonium sulfate and acetic acid also remained in the extracts. Judging from the volume of $0.2 \mathrm{M}$ $\mathrm{Na}_{2} \mathrm{HPO}_{4}$, pH 9.4, necessary to neutralize urine extracts, a relatively constant volume of $10 \mu \mathrm{l} /$ tube of $75 \%$ saturated ammonium sulfate in $0.5 \mathrm{v} / \mathrm{v} \%$ acetic acid was estimated to be carried over. Because the presence of such a small amount of ammonium sulfate and acetic acid in the RIA system had a small but significant influence on ${ }^{125} \mathrm{I}-\mathrm{SmC}$ binding, $10 \mu \mathrm{l}$ of $75 \%$ saturated ammonium sulfate in $0.5 \mathrm{v} / \mathrm{v} \%$ acetic acid and $100 \mu \mathrm{l}$ of $0.2 \mathrm{M}$ $\mathrm{Na}_{2} \mathrm{HPO}_{4}$ also were added to the standard $\mathrm{SmC}$ solutions in place of the equal volume of the assay buffer. Otherwise RIA procedures were the same as mentioned above.

The $\mathrm{SmC}$ concentration measured in urine was corrected for the recovery of unlabeled $\mathrm{SmC}$ assessed in each assay by measurement of $0.4 \mathrm{ng} /$ tube of the unlabeled hormone dissolved in 1 $\mathrm{ml}$ of $0.5 \mathrm{v} / \mathrm{v} \%$ acetic acid containing $0.01 \%$ BSA.

Creatinine concentration in urine was measured by the Jaffé reaction using an autoanalyzer (Hitachi Medical Corporation, no. 736, Tokyo, Japan). Immunoreactive $\mathrm{SmC}$ in urine was expressed as $\mathrm{ng} / \mathrm{mg}$ creatinine. Statistical significance for age and sex differences were determined by the unpaired $t$ test.

\section{RESULTS}

The gel chromatographic pattern of immunoreactive $\mathrm{SmC}$ is shown in Figure 1. Most of immunoreactivity was eluted coincident with the radioactive peak of ${ }^{125} \mathrm{I}-\mathrm{SmC}$. Also there was a minor peak of approximate mol. wt. 30,000-40,000.

In our RIA system for urine SmC, the binding of ${ }^{125} \mathrm{I}-\mathrm{SmC}$ in the absence of the unlabeled hormone was $40 \sim 50 \%$ of total radioactivity applied. "Nonspecific" binding in the absence of the first antibody was less than $3 \%$. The sensitivity of SmC RIA system was $0.01 \mathrm{ng} /$ tube and about $0.35 \mathrm{ng} /$ tube of unlabeled SmC gave $50 \%$ displacement of ${ }^{125} \mathrm{I}-\mathrm{SmC}$ binding. The recovery of radiolabeled $\mathrm{SmC}$ through the extraction was $94.9 \pm 2.6 \%$ ( $n$ $=10$, mean $\pm \mathrm{SD})$. When $0.4 \mathrm{ng} /$ tube of unlabeled $\mathrm{SmC}$ was extracted and measured by RIA, the recovery of immunoreactivity was $72.2 \pm 3.3 \%$ ( $n=5$ assays). The extraction rate of the salts checked with $\mathrm{Na}^{125} \mathrm{I}$ was less than $2 \%$. Parallelism between standard and extracted urine is shown in Figure 2. The intraassay coefficient of variation for the RIA system, including the extrac-

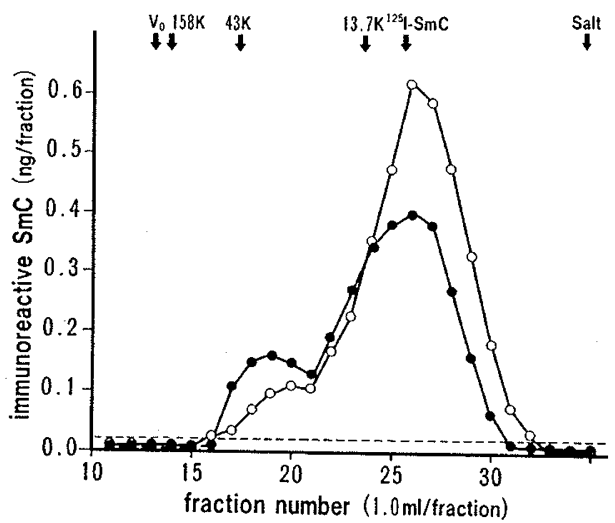

Fig. 1. Gel filtration profiles of immunoreactive $\mathrm{SmC}$ in urine from a normal female adult $(\mathrm{O} \longrightarrow \mathrm{O})$ and a newborn $(\longrightarrow)$. Twenty $\mathrm{ml}$ of urine samples were concentrated, dialyzed, applied on a $0.95 \times 45 \mathrm{~cm}$ Sephadex G-100 column, and eluted with 0.01 M PBS containing $0.1 \%$ BSA, pH 7.4. Each fraction was assayed by RIA for SmC. Calibration was made with blue dextran $(\mathrm{Vo})$, aldolase $(158 \mathrm{~K})$, ovalbumin $(43 \mathrm{~K})$, ribonuclease $\mathrm{A}(13.7 \mathrm{~K}),{ }^{125} \mathrm{I}-\mathrm{SmC}$, and $\mathrm{Na}^{125} \mathrm{I}$ (salt).

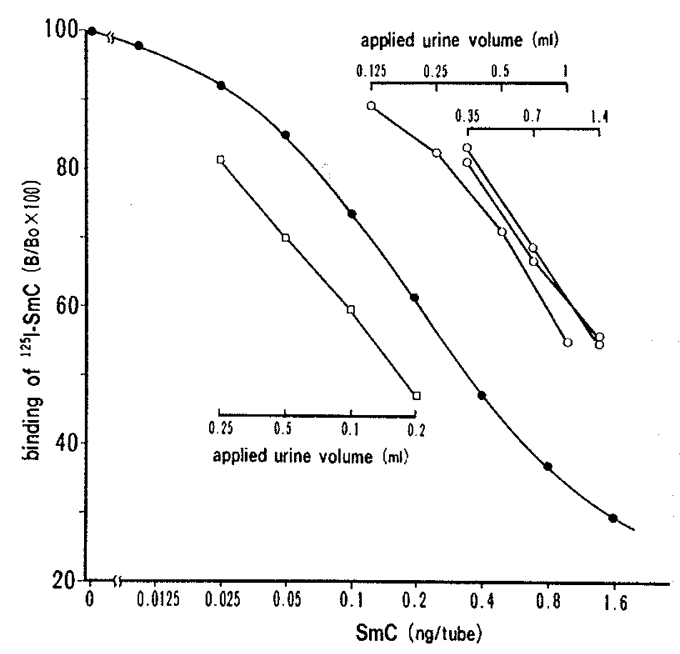

Fig. 2. Standard curve for urine SmC RIA. Urine specimens from three normal children $(\mathrm{O}-\mathrm{O})$ and an active acromegalic $(\square-\square)$ were used for this dilution study.

tion process, was 7.5 and $11.8 \%(n=10)$ for the urine samples containing 0.36 and $0.09 \mathrm{ng} / \mathrm{ml}$ of $\mathrm{SmC}$, respectively. When urine specimens from a normal adult stored at $4^{\circ} \mathrm{C}$ were measured at $1,8,35$, and 70 days of storage, the values were 0.21 , $0.16,0.17$, and $0.19 \mathrm{ng} / \mathrm{ml}$, respectively.

Urinary concentrations of SmC from normal subjects of different ages are summarized in Figure 3 . As the distribution of the values was skewed and tended to spread more widely toward the higher side, normal distribution was estimated after logarithmic conversion. All the statistical analyses, therefore, were based on the logarithmic values. There were no statistical male-female differences in any age groups though values in females tended to be higher than those in males at 8-9 yr and in adults (data not shown). Age-dependent changes were statistically significant as shown in Figure 3.

Data from patients with abnormal hGH status are summarized in Figure 3. In pituitary dwarfs, all of 15 had lower SmC concentrations than the averages for age matched controls, while six had the values less than the lower limits of normal (mean 2 SD). However, three acromegalic subjects had concentrations much higher than the normal range. 


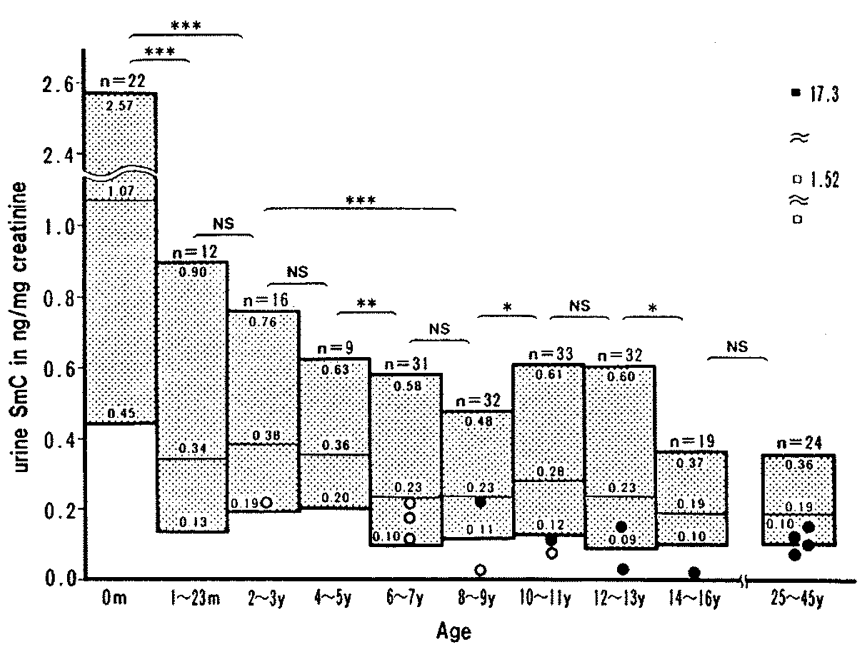

Fig. 3. Normal values for urine $\mathrm{SmC}$ according to age. The horizontal bars and shaded columns represent mean \pm 2 SD (data based on logarithmic values) obtained from 230 normal urine samples. Statistical significance between each age group is shown with $p$ values $<0.05\left(^{*}\right)$ $<0.01\left(^{* *}\right)$, or $<0.001\left(^{* * *}\right)$. Urine SmC levels from 15 pituitary dwarfs (male $\bullet$, female $O$ ) and three active acromegalics (male $\mathbf{\square}$, female $\square$ ) also are shown according to their age.

\section{DISCUSSION}

Our gel chromatographic study revealed that immunoreactive $\mathrm{SmC}$ is present in urine and most of the immunoreactivity is eluted with ${ }^{125} \mathrm{I}-\mathrm{SmC}$, suggesting that most of the urinary material is monomeric SmC. A small portion of the immunoreactivity also was found at an approximate mol. wt. of 30,000-40,000. Because oligomeric SmC is unlikely (6), immunoreactive SmC of high molecular weight may indicate that $\mathrm{SmC}$ is bound by the small MW binding protein that is present in human plasma (7) or it may represent a precursor form of $\mathrm{SmC}$ that is ordinarily not found in plasma (8).

As the concentration of $\mathrm{SmC}$ in urine was approximately onethousandth of the plasma level, its measurement required extraction, i.e. concentration and desalting, preceeding RIA. Acid ethanol extraction, as reported for plasma $\operatorname{SmC}(9)$, also may be effective in urine, but an inconveniently large amount of acid ethanol would be required. Although ammonium sulfate precipitation usually is suitable for polypeptides of high molecular weight, we observed that $62 \sim 85 \%$ saturated ammonium sulfate precipitated about $95 \%$ of radioactive SmC added to urine. In addition, the extraction study with ionic ${ }^{125} I$ revealed that this step was also effective in removing urinary salts. However, when the extraction was performed at a neutral $\mathrm{pH}$, the precipitate was sometimes unexpectedly large in amount and remained insoluble thereafter. In contrast, an acidic condition at around $\mathrm{pH} 4$, i.e. final $0.5 \mathrm{v} / \mathrm{v} \%$ acetic acid added to urine, resolved this problem. Another unexpected observation was that ${ }^{125} \mathrm{I}-\mathrm{SmC}$ in $0.5 \mathrm{v} / \mathrm{v} \%$ acetic acid, not in urine, was fully extracted only when no less than $0.003 \%$ of BSA was added to the solution. This phenomenon was not explained by the adsorption of ${ }^{125} \mathrm{I}-\mathrm{SmC}$ to the tube walls. Thus our extraction method involved addition of BSA as well as acetic acid in order to achieve a consistently high extraction rate. As a whole, our system of extraction is simple and inexpensive and achieves a constant and relatively high recovery rate, satisfactory coefficients of variation, a parallel relationship between standard and sample dilution, and sufficient sensitivity for $\mathrm{SmC}$ determination in urine.

Most striking among the normal values is the very high urine $\mathrm{SmC}$ level in the newborn. Because the values are expressed as $\mathrm{ng} / \mathrm{mg}$ creatinine, this may be partly explained by the low urinary excretion of creatinine in the neonatal period (10). In addition, immature renal function may result in enhanced excretion of $\mathrm{SmC}$ together with various plasma proteins (11). But, in light of the fact that plasma SmC concentrations are known to be low at this age (12), the discrepancy in the concentrations between plasma and urine may be important. It may be noteworthy that $\mathrm{SmC}$ concentrations in urine, and not in plasma, are high in early infancy when somatic growth is very rapid. A slight elevation of SmC was observed at early puberty when the plasma concentration also is raised (12).

Growth hormone-deficient children tended to excrete smaller amounts of $\mathrm{SmC}$ in urine. Inasmuch as there was a considerable degree of overlap with the normal range, urine $\mathrm{SmC}$ alone does not seem to be of great diagnostic value. However, our observation is preliminary, as our series is small and contains children with hGH deficiency of various degree. On the other hand, active acromegaly is associated with elevated levels of $\mathrm{SmC}$ in urine as well as in plasma. It seems likely that the measurement of urine $\mathrm{SmC}$ will be useful in the diagnosis of active acromegaly.

It is worth noting that the urinary concentrations of $\mathrm{SmC}$ are in most cases only $0.1 \sim 1 \mathrm{ng} / \mathrm{ml}$ and much lower than one may have expected from its plasma concentrations. Judging from the gel chromatographic patterns of immunoreactive SmC in urine (Fig. 1), it is possible that free SmC and a small portion of bound $\mathrm{SmC}$ in plasma are excreted via glomerular filtration. Because the concentration of free $\mathrm{SmC}$ in plasma is thought to be very low (7), this hypothesis may explain the discrepant concentrations of SmC in plasma and in urine. However, it is also possible that $\mathrm{SmC}$ is secreted by the renal tubules. In addition, locally produced $\mathrm{SmC}(13,14)$ may be excreted in urine as is the case for epidermal growth factor (15), so far the source of urine SmC remains unclear.

$A C K N O W L E D G M E N T S$. The authors thank Fujisawa Pharmaceutical Co. for generously providing the recombinant SmC and the antiserum. We are grateful to Miss S. Igarashi, Director of Kanagawa Health Service Association, and the healthy volunteers who provided normal urine specimens. We also thank Dr. M. Sasaki and Mrs. H. Sakuma of Yokohama-MinamiKyosai Hospital for the measurement of urine creatinine. The helpful advice of Dr. L. E. Underwood, University of North Carolina, is gratefully acknowledged.

\section{REFERENCES}

1. Reiter EO, Kulin HE, Hamwood SM 1973 Preparation of urine containing small amounts of FSH and LH for radioimmunoassay: comparison of the kaolin-acetone and acetone extraction techniques. J Clin Endocrinol Metab 36:661-665

2. Miller M, Moses A 1972 Urinary antidiuretic hormone in polyuric disorders and in inappropriate ADH syndrome. Ann Intern Med 77:715-721

3. Baumann G, Abramson EC 1983 Urinary growth hormone in man: evidence for multiple molecular forms. J Clin Endocrinol Metab 56:305-311

4. Saito Y, Yamada H, Niwa M, Ueda I 1987 Production and isolation of recombinant somatomedin C. J Biochem 101:123-134

5. Zapf J, Walter H, Froesch ER 1981 Radioimmunological determination of insulinlike growth factors $I$ and II in normal subjects and in patients with growth disorders and extrapancreatic tumor hypoglycemia. J Clin Invest 68:1321-1330

6. Dafgård E, Bajaj M, Honegger AM, Pitts J, Wood S, Blundell T 1985 The conformation of insulin-like growth factors: relationships with insulins. $J$ Cell Sci 3(suppl):53-64

7. Hintz RL 1986 The somatomedin binding proteins. In: Raiti S, Tolman RA (eds) Human Growth Hormone. Plenum Medical Book Co., New York, pp 553-561

8. Rotwein P, Pollock KM, Didier DK, Krivi GG 1986 Organization and sequence of the human insulin-like growth factor I gene. J Biol Chem 261:4828-4832

9. Daughaday WH, Mariz IK, Blethen SL 1980 Inhibition of access of bound somatomedin to membrane receptor and immunobinding sites: a comparison of radioreceptor and radioimmunoassay of somatomedin in native and acid ethanol-extracted serum. J Clin Endocrinol Metab 51:781-788

10. Henry RJ 1968 Creatinine and creatine. In: Clinical Chemistry-Principles and Technics. Harper and Row Publishers, New York, pp 287-302

11. Galaske RG 1986 Renal functional maturation: renal handling of proteins by 
mature and immature newborns. Eur J Pediatr 145:368-371

12. Underwood LE, Smith EP, Van Wyk JJ, Clemmons DR, D'Ercole AJ, Pandian MR, Preece MA, Moore WV 1986 Somatomedin C/insulinlike growth factor I-regulation and clinical applications. In: Raiti S, Tolman RA (eds) Human Growth Hormone. Plenum Medical Book Co., New York, pp 609-619

13. Stiles AD, Sosenko IRS, D'Ercole AJ, Smith BT 1985 Relation of kidney tissue somatomedin $\mathrm{C} /$ insulin-like growth factor I to postnephrectomy renal growth in the rat Endocrinology 117.2397-2401

14. Davoren JB, Hsueh AJW 1986 Growth hormone increases ovarian levels of immunoreactive somatomedin C/insulin-like growth factor I in vivo. Endocrinology 118:888-890

15. Mattila A-L, Pasternack A, Viinikka L, Perheentupa J 1986 Subnormal concentrations of urinary epidermal growth factor in patients with kidney disease. J Clin Endocrinol Metab 62:1180-1183

\section{Announcement}

\section{Meeting of the European Society for Pediatric Research}

The meeting will take place June 19-22, 1988 at the University Center, Blindern, Oslo, Norway. It will include plenary sessions devoted to neonatology, cardiology, and cellular growth factors. Organized symposia topics will include: oxygen toxicity and free radicals, Reye's syndrome, surfactant, extracorporeal membrane oxygenation, high frequency ventilation, mineral metabolism, prevention and management of pain, cellular growth factors, and fetal echocardiography.

Official language for the meeting will be English.

Deadline for abstracts: February 15, 1988; deadline for early registration: March 15, 1988.

For more information contact the President: Professor Sverre Halvorsen, Department of Pediatrics, Ullevål Hospital, 0407 Oslo 4, Norway, Phone: (47 2) 4618 70. or Organizing Secretariat, ESPR 1988, Congress Service, PO Box 55, Blindern, 0313 Oslo 3, Norway. 